\title{
The Spatial Distribution of Tourist Sites in Samosir, North Sumatera
}

\author{
*Sugiharto, Fitra Delita, and Tumiar Sidauruk \\ Departement of Geography Education, Faculty of Social Science, Universitas Negeri Medan, Indonesia \\ Email: sugihunimed@gmail.com delitafitra@gmail.com
}

*Corresponding Author, Received: May 14, 2019, Revised: May 18, 2019, Accepted: May 31, 2019

This is an open acces article distributed under the Creative Commons 4.0 Attribution License, wich permits unrestricted use, Distribution. and reproduction in any medium provided the original work is properly cited @2017 by author and Universitas Negeri Padang

\begin{abstract}
The spatial distributions of tourist sites is one of basic components to formulating the tourism development policy based on their characteristics and promote tourist sites. GIS technology very helpfull to develop many kinds of sectors including tourism sectors. This research aims to map the distribution of tourist sites in Samosir District. The data used are compiled from observation and survey. Furthermore, the data were analyzed using Arc GIS software to obtain the map of tourist sites in Samosir district. The results reveals that almost 75 tourist attractions spread in 9 subdistricts in Samosir. Distribution of most sites is located mostly in the subdistrict of Simanindo and least in Sitiotio district. Tourism supporting infrastructure facilities such as hotels and other accommodations are also most in Simanindo district.
\end{abstract}

Keywords: Distribution, Tourist Sites, GIS

\section{Introduction}

Samosir became one of the famous destination of tourism in Indonesia. Samosir offers natural attractions and a wealth of unique local culture to atrack the tourists. Samosir regency keeps the history of Batak ethnic origin. Various relics of the history of the Batak kingdom be evidence of the past tribal life such as the Tomb of the King, Stone Trials and others. Not only that, in terms of culture also contribute to the development of tourism, especially the culture of Batak tribe such as custom events, ulos crafts and so forth. Natural attractions are distributed in every subdistrict in Samosir. However, not all potential objects are popular and visited by tourists.

Geographic information Systems (GIS) is one amongst the most outstanding technologic innovations in touristry designing and decision making. Both GIS and tourism share a typical characteristic, that is, each cross the boundaries of disciplines and application areas. GIS has been applied in several fields together with geography, forestry, urban development and designing, and environmental studies (Hermon, 2009; Baviskar, 2017; Hermon, 2017). GIS can be used in tourism as a decision supporting tool for sustainable tourism planning, impact assessment, visitor flow management, and tourism site selection. Therefore, the potential for GIS applications in tourism is significant. Geographic Information System (GIS) has been recognized as a useful tool by a wide range of disciplines in managing, storing, analyzing and visualizing the spatial and non-spatial data.

The outcomes of GIS analysis demonstrate the spatial visualization of the lodging evolution and geographical distribution trends within the study areas. This study provides tourism planners, local authorities, hotel entrepreneurs and potential developers with insights into the planning and constructing of new tourist accommodations according to potential development sites/areas (Othman et al, 2010; Hermon, 2010; Hermon, 2012). Tourism with its focus on travel movements and the transfer of peoples, goods and 
services spatially and temporally is essentially a geographical phenomenon (Williams, 2009; Hermon, 2015; Hermon, 2016; Oktorie, 2017; Hermon, 2019). The tourist resources are spatially distributed across spaces in countries, and geographies, this entails understanding the spatial dimensions of tourism and geographical unpacking of the uneven patterns and distribution of resources as key socio-economic development (Rogerson, 2014; Hermon, 2016). Therefore, the purpose of this study is to map the spatial distribution of natural attractions, history and culture as well as the object of spiritual/religious tourism in Samosir District. From the result of this study, tourists can be more familiar with the distribution of sites throughout the District of Samosir. This of course can be used as a tourism promotion medium.

\section{Method}

Qualitative approach are used in this research. The data are compiled from observation and survey. The research location covers 9 subdistrict namely Sitiotio, Simanindo, Pangururan, Sianjur Mula-mula, Harian, Nainggolan, Onanrunggu, Palipi, and Ronggur Nihuta. In each district, tourism inventory is then classified into several categories, namely (1) natural tourism (geophysical-landscape atraction, natural atraction); (2) historical tourism; (3) culture tourism; (4) religious tourism; (Department of Tourism, Art and Culture of Samosir District in BPS, 2016; Brown et al., 2007). The coordinates of its area determined by using Global Positioning System. Furthermore, the spatial and attribute data were analyzed using Arc GIS software to produce the map of tourism sites in Samosir District. The research flow diagram can be seen in the following scheme:

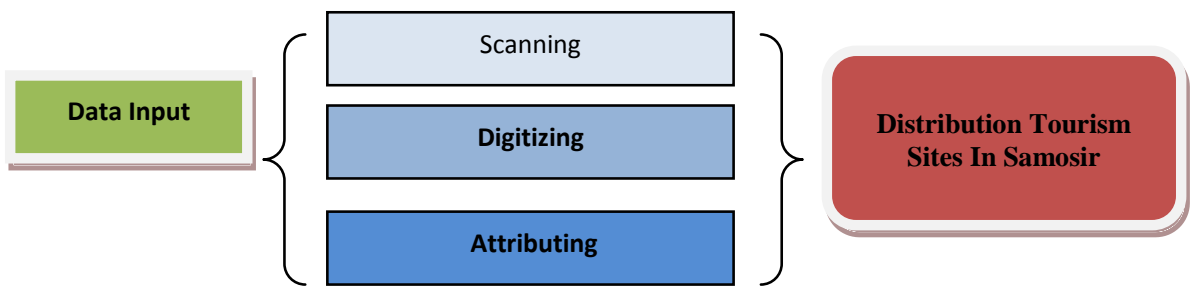

Figure 1. Flow Diagram of Research

\section{Result and Discussion}

There are 75 tourist sites spread in 9 subdistricts in Samosir District. Of these, as many as 39 objects $(52 \%)$ are natural sites, 14 historical sites (18.67\%), 9 cultural sites (12\%), 12 historical and cultural sites $(16 \%)$, and 1 spiritual attraction $(0.013 \%)$. Most destinations are in Simanindo subdistrict and at least in Sitiotio subdistrict. Whereas tourism facilities are needed in the development of tourist destinations (Jovanovic, 2008). Tourist attraction would be of little value of it's locations were inaccessible by transportation. Physical isolation and inadequate transport facilities are, clearly, handicaps to tourism. The following are the names of tourist sites per sub-district in Samosir District are grouped based on the type of tourist sites equipped with distribution map.

\section{Simanindo Subdistrict}

Simanindo area is $198.20 \mathrm{~km}^{2}$ (13.72\% of the region of Samosir district). The capital of the subdistrict is Ambarita. There are 58 hotels (1326 rooms) and other accommodation to support 19 tourist sites in this area. Only 1 hotel which is a 1 star hotel. Others, consist of 2 star hotels totaling 5 buildings; class I jasmine hotels amounted to 30 buildings; class II jasmine hotel amounted to 17 buildings; and class III jasmine hotel amounted to 5 buildings. Tourism sites in Subdistrict of Simanindo can be observed in Table 1 below: 
ISSN: 2580-4030 (Print) 2580-1775 (Online)

Vol 3, No. 1, (pp. 1-9), June, 2019

http://sjdgge.ppj.unp.ac.id

Table 1. Distribution of Tourist Sites in Subdistrict of Simanindo

\begin{tabular}{rllrlr}
\hline No & Name of sites & Type of sites & No & Name sites & Type of sites \\
\hline 1 & Makam Raja Sidabutar & History and Culture & 11 & Desa Wisata Tuk-tuk Siadong & Natural \\
2 & Sipokki & History and Culture & 12 & Siulak Hosa bukit Beta & Natural \\
3 & Museum Huta Bolon & History and Culture & 13 & Tuk-tuk Siasu & Natural \\
4 & Museum Tomok & History and Culture & 14 & Pulo Malau & Natural \\
5 & Museum Gok Asi & History and Culture & 15 & Agrowisata Aek Naktonang & Natural \\
6 & Batu Marhosa & History and Culture & 16 & Gua Lontung & Natural \\
7 & Situs Pagar Batu & History and Culture & 17 & Gua Alam Sangkal & Natural \\
8 & Pertunjukan Sigale-Gale & Culture & 18 & Pantai Sibolazi & Natural \\
9 & Batu Parsidangan & History & 19 & Pantai Batu Hoda & \\
10 & Batu Kursi Parhapuran & History & & & \\
\hline
\end{tabular}

Distribution of the tourist sites in Simanindo Subdistrict showed in Figure 2 below :

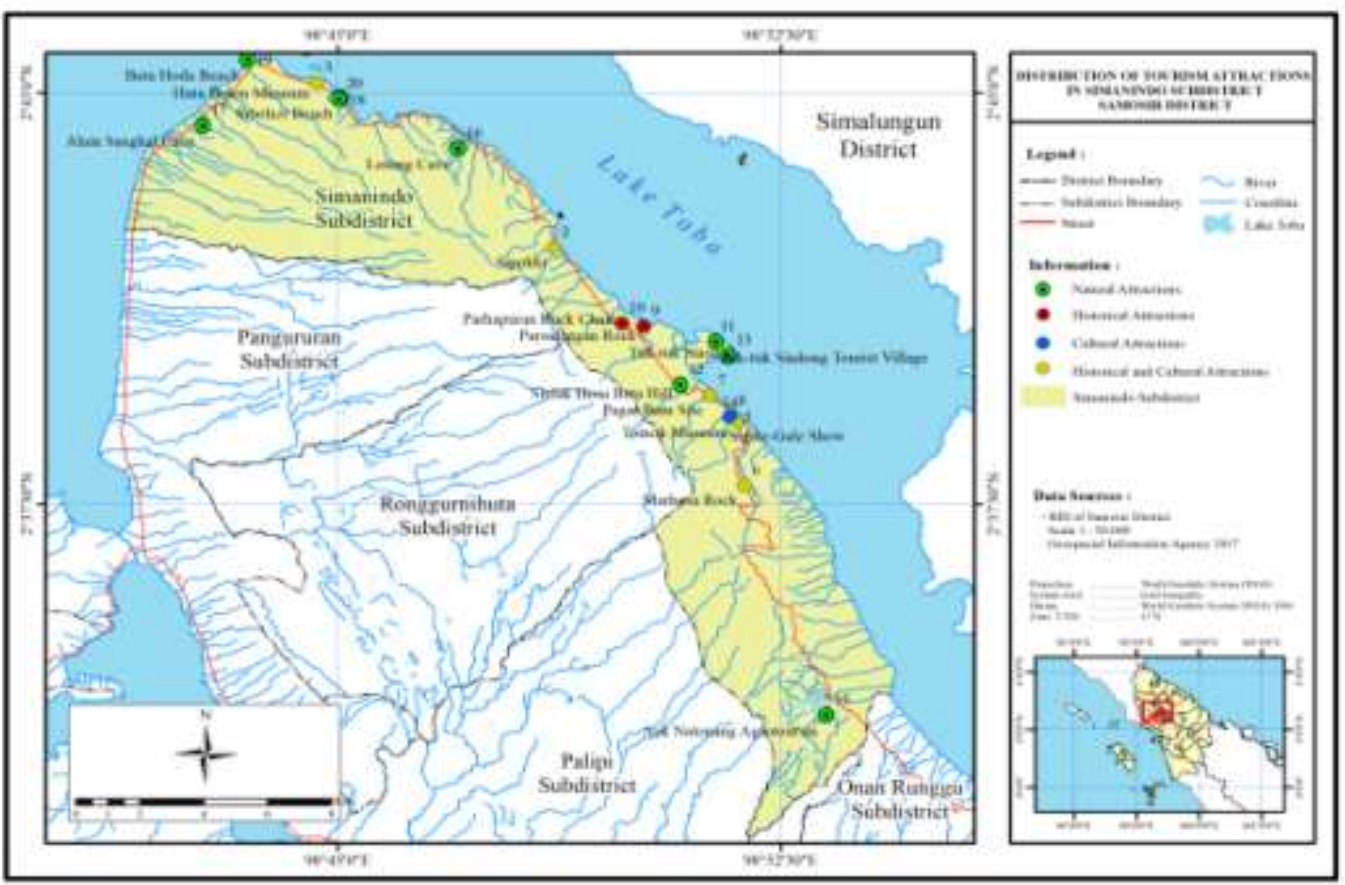

Figure 2. Map of Distribution of Tourist Sites in Simanindo Subdistrict

\section{Subdistrict of Pangururan}

Its area is $121.43 \mathrm{~km}^{2}$ with a capital subdistrict is Pangururan. There are 18 jasmine hotels (12 Iclass jasmine hotels, 4 second-class jasmine hotels, 2 3-star jasmine hotels) with 315 rooms. Tourist sites in Pangururan subdistrict can be observed in Table 2.

Table 2. Distribution of Tourist Sites in Subdistrict of Pangururan

\begin{tabular}{llllll}
\hline No & Name of Sites & Type of Sites & No & Name of Sites & Type of Sites \\
\hline 1 & $\begin{array}{l}\text { Komunitas Tenun Ulos Batak Huta } \\
\text { Raja Lumban Suhi-Suhi }\end{array}$ & $\begin{array}{l}\text { History and } \\
\text { Culture }\end{array}$ & 6 & $\begin{array}{l}\text { Monumen Perjuangan Liberty } \\
\text { Malau }\end{array}$ & Culture \\
2 & $\begin{array}{l}\text { Sopo Paromasan Di Desa Lumban } \\
\text { Pinggol }\end{array}$ & History & 7 & Kawasan Tano Ponggol & Natural \\
3 & Kawasan Pohon Baru Naibaho & History & 8 & Pantai Pasir Putih Parbaba & Natural \\
4 & Kawasan Pohon Baru Sinaetang & History & 9 & Pemandian Air Panas & Natural \\
5 & Museum Gereja Katolik Inkulturatif & Culture & 10 & Pantai Indah Situngkir & Natural \\
\hline
\end{tabular}


ISSN: 2580-4030 (Print) 2580-1775 (Online)

Vol 3, No. 1, (pp. 1-9), June, 2019

http://sjdgge.ppj.unp.ac.id

Distribution of the tourist sites in Pangururan Subdistrict showed in Figure 3 below:

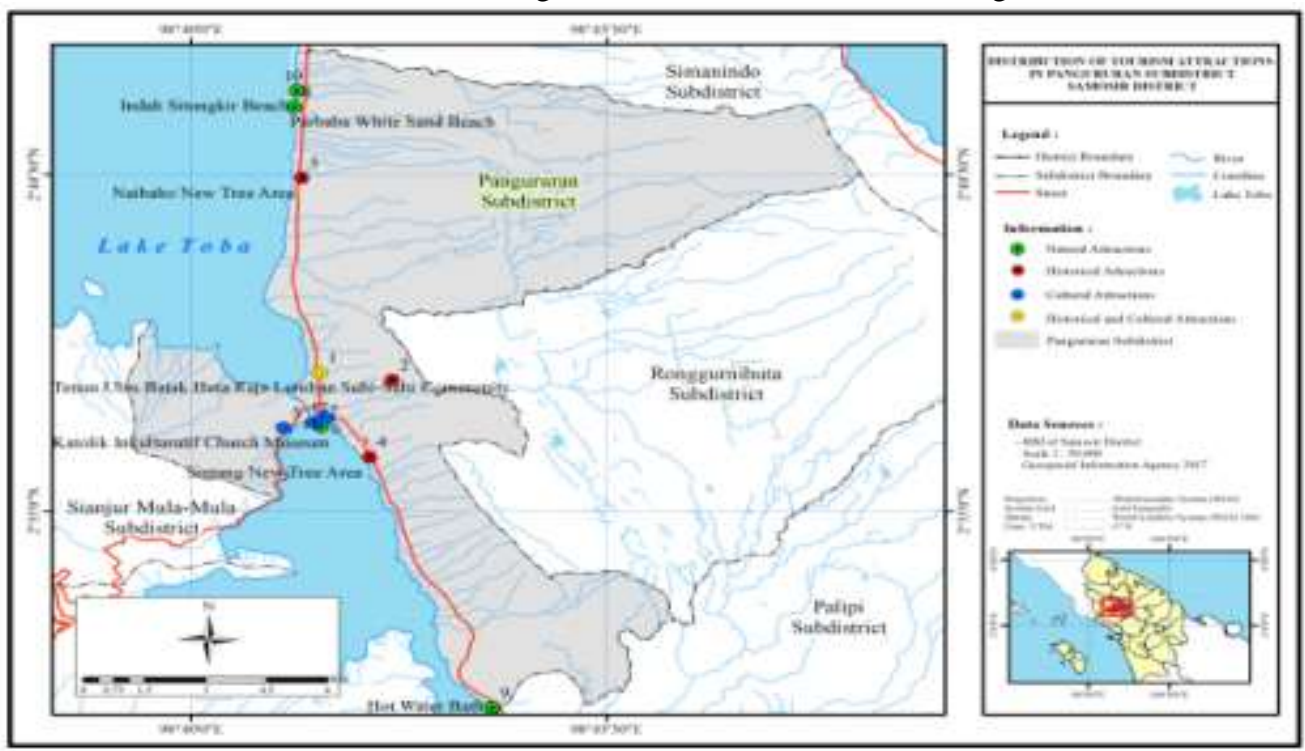

Figure 3. Map of Distribution of Tourist Sites in Pangururan Subdistrict

\section{Subdistrict of Sitiotio}

Covers an area of $50.76 \mathrm{~km}^{2}$ with capital of subdistrict is Sabulan. Sitiotio Subdistrict has no hotel or other accommodation that supports 3 tourist sites in this area. The sites can be observed in Table 3 .

Table 3. Distribution of Tourist Sites in Sitiotio Subdistrict

\begin{tabular}{lll}
\hline No & Name of Sites & Type of Sites \\
\hline 1 & Patung Raja Silontung & History and Culture \\
2 & Mual Datu Parngongo & History \\
3 & Mual Boru Saroding Desa Sabulan & History \\
\hline
\end{tabular}

Distribution of the tourist sites in Sitiotio Subdistrict showed in Figure 4.

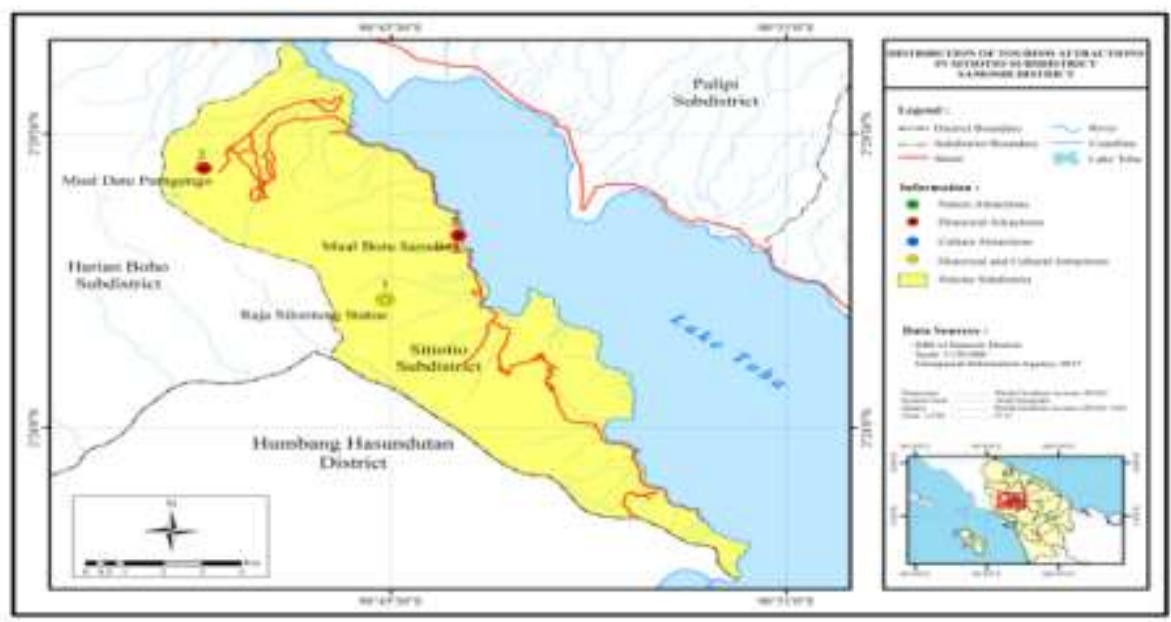

Figure 4. Map of distribution of Tourist Sites in Sitiotio Subdistrict 


\section{Subdistrict of Palipi}

Its area of $129.55 \mathrm{~km}^{2}$ with the capital of the subdistrict is Mogang. Its position is located on the west side of the lake adjacent to the Simanindo Subdistrict, on the east side of the lake. Tourist sites in this area are shown in Table 4 and Figure 5.

Table 4. Distribution of Tourist Sites in Palipi Subdistrict

\begin{tabular}{lll} 
No & Name of Sites & Type of Sites \\
\hline 1 & Martua Limang di Desa Suhul Ni Huta Pardomuan Urat & History \\
2 & Kawasan Wisata Gua Bunda Maria & Religion \\
3 & Batu Rantai & Natural \\
4 & Pemandian Air Panas Simbolon & Natural
\end{tabular}

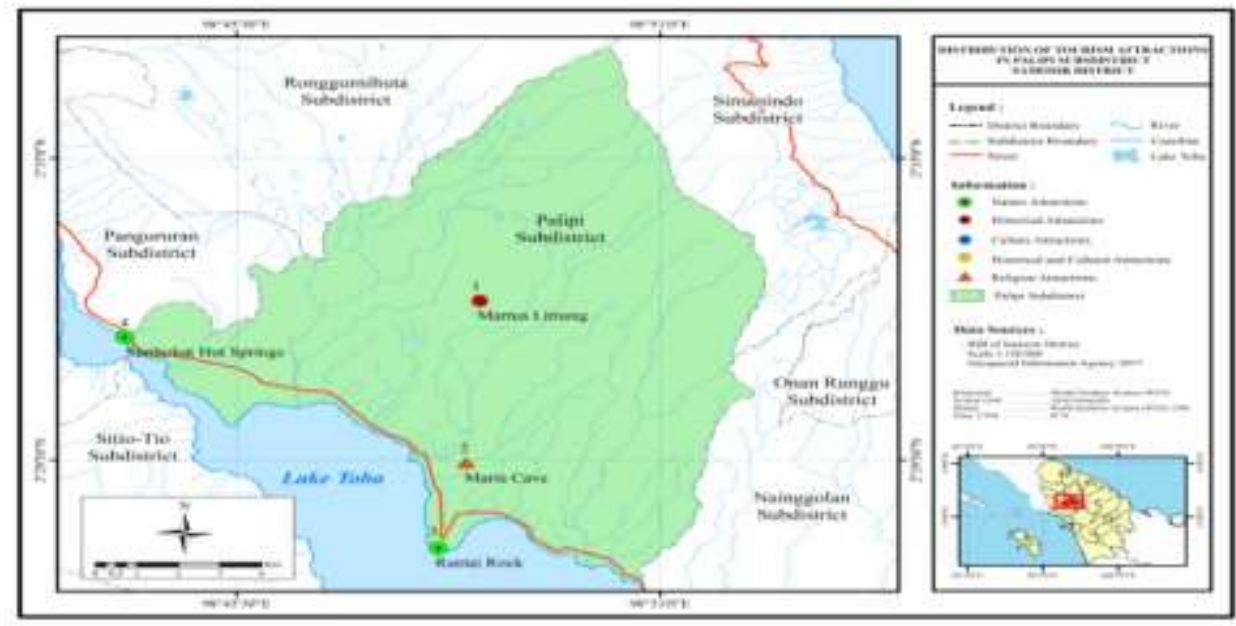

Figure 5. Map of Distribution of Tourist Sites in Palipi Subdistrict

\section{Subdistrict of Sianjur Mula-mula}

The area of $140,24 \mathrm{~km}^{2}$ with the capital of the subdistrict is Ginolat. The region is surrounded by hills and paddy fields. Pusuk Buhit is one of a hill peak in this region, 1972 masl (meters above sea level), based on the local mythology is believed to be the point of origin of Batak tribe originated. Sianjur Mulamula has 15 tourist sites. List of sites in the Sianjur Mula-mula subdistrict can be observed in Table 5 and Figure 6.

Table 5. Distribution of Tourist Sites of Sianjur Mula-Mula Subdistrict

\begin{tabular}{|c|c|c|c|c|c|}
\hline No & Name of Sites & Type of Sites & No & Name of Sites & Type of Sites \\
\hline 1 & $\begin{array}{l}\text { Pusuk Buhit (Batu Sawan, Tala, } \\
\text { Tempat Doa }\end{array}$ & History and Culture & 9 & Batu Parhusipan & Culture \\
\hline 2 & $\begin{array}{l}\text { Kawasan Peningalan Sejarah Huta Si } \\
\text { Raja Batak }\end{array}$ & History and Culture & 10 & Batu Nanggar & Culture \\
\hline 3 & Pemandian Aek Sipitu Dai & History and Culture & 11 & Batu Sawan & Culture \\
\hline 4 & Batu Hobon & History & 12 & Aek Si Boru Pareme & Natural \\
\hline 5 & Komplek Guru Tatea Bulan & History & 13 & Batu Holbung & Natural \\
\hline 6 & $\begin{array}{l}\text { Perkampungan Si Raja Batak di } \\
\text { Sigulatti }\end{array}$ & History & 14 & $\begin{array}{l}\text { Air Terjun Hadabuan } \\
\text { Nasogo }\end{array}$ & Natural \\
\hline 7 & Aek Boras & Culture & 15 & Pulau Tulas & Natural \\
\hline 8 & Batu Pangarsipan & Culture & & & \\
\hline
\end{tabular}


ISSN: 2580-4030 (Print) 2580-1775 (Online)

Vol 3, No. 1, (pp. 1-9), June, 2019

http://sjdgge.ppj.unp.ac.id

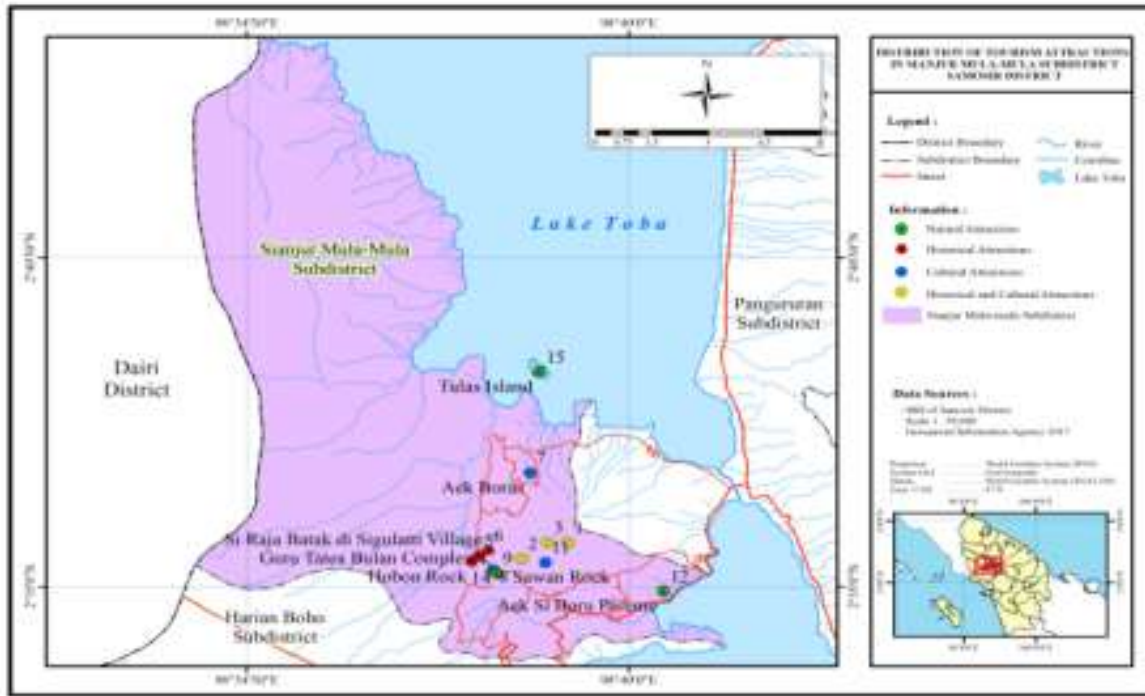

Figure 6. Map of Distribution of Tourist Sites in Sianjur Mula-Mula Subdistrict

\section{Subdistrict of Onanrunggu}

Covers an area of $60,89 \mathrm{~km}^{2}$ with capital of subdistrict is Onanrunggu. This Subdistrict has a list of tourist attractions shown in table 6 and figure 7.

Table 6. Distribution of Tourist Sites in Onanrunggu Subdistrict

\begin{tabular}{lll}
\hline No & Name of Sites & Type of Sites \\
\hline 1 & Mual Si Raja Sonang Di Pakpahan & History \\
2 & Tambun Surlau & Culture \\
3 & Pantai Pasir Putih Di Sukkean & Natural \\
4 & Kawasan Wisata Remaja Lagundi & Natural \\
5 & Pohon Besar Sukkean & Natural \\
\hline
\end{tabular}

Distribution of the tourist sites in Onanrunggu Subdistrict showed in figure 7 below :

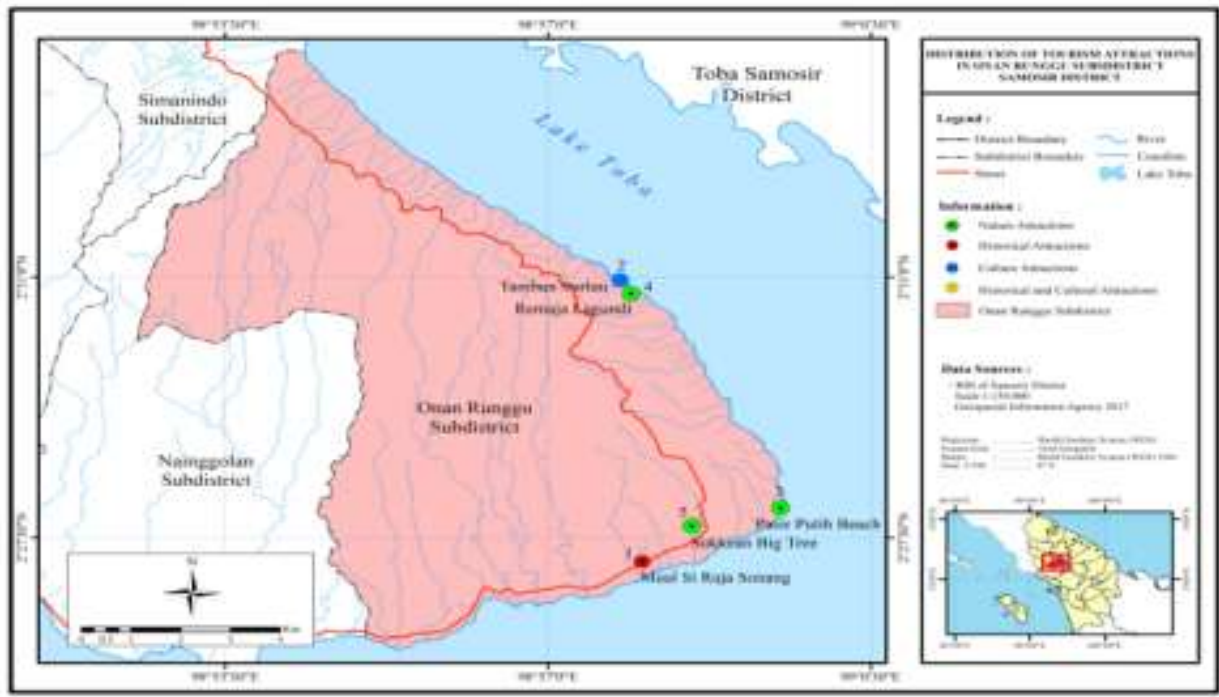

Figure 7. Map of Distribution of Tourist Sites in Onanrunggu Subdistrict 
ISSN: 2580-4030 (Print) 2580-1775 (Online)

Vol 3, No. 1, (pp. 1-9), June, 2019

http://sjdgge.ppj.unp.ac.id

\section{Subdistrict of Nainggolan}

The total area of $87,86 \mathrm{~km}^{2}$, with the subdistrict capital is Nainggolan. Tourist sites in this area are shown in Table 7 below.

Table 7. Distribution of Tourist Sites in Nainggolan Subdistrict

\begin{tabular}{lll}
\hline No & Name of Sites & Type of Sites \\
\hline 1 & Boru Simenak-Menak & History \\
2 & Sidabasa & History \\
3 & Pantai Pasir Putih & Natural \\
4 & Batu Guru & Natural \\
5 & Polhang & Natural \\
\hline
\end{tabular}

Distribution of the tourist sites in Nainggolan Subdistrict Showed in Figure 8:

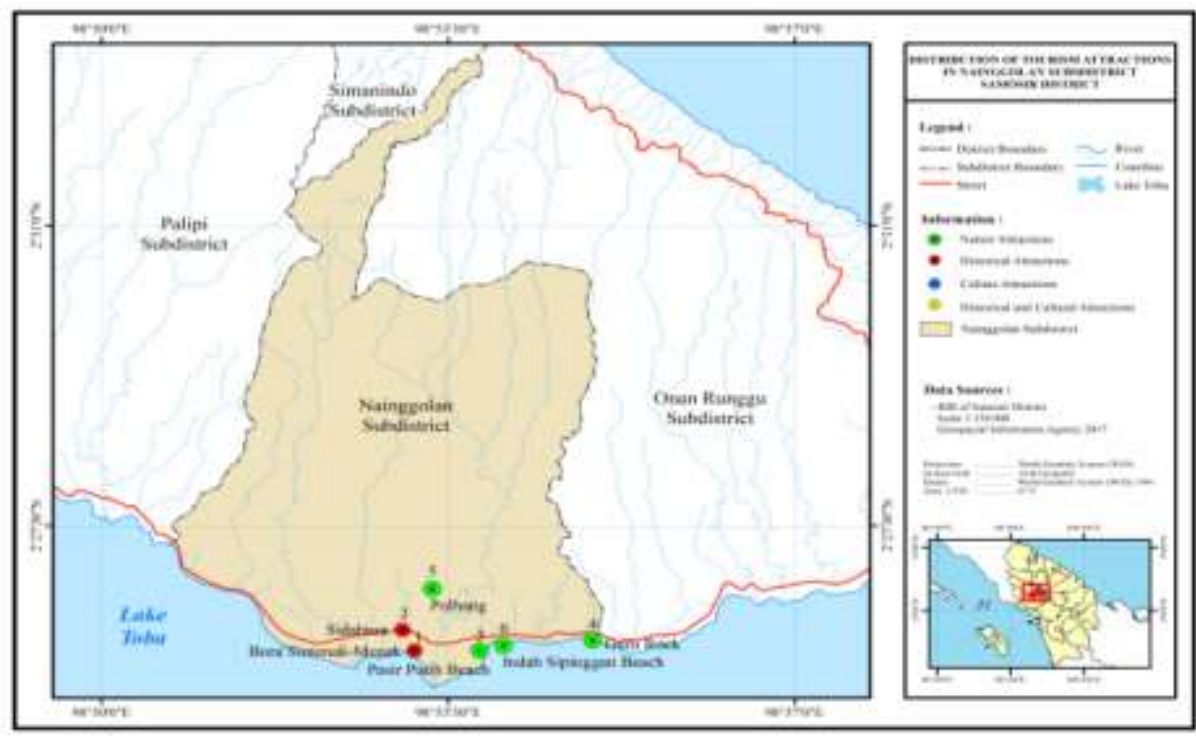

Figure 8. Map of Distribution of Tourist Sites in Onanrunggu Subdistrict

\section{Subdistrict of Harian Boho}

Its total area is $560.45 \mathrm{~km}^{2}$ (its territory is the widest compared to 8 other districts). The subdistrict capital is Harian Boho. Tourist destinations in this area are shown in Table 8.

Table 8. Distribution of Tourist Sites in Harian Boho Subdistrict

\begin{tabular}{lll}
\hline No & Name of Sites & Type of Sites \\
\hline 1 & Air Terjun Sampuran Efrata Sosor Dolok & Natural \\
2 & Menara Pandang Tele & Natural \\
3 & Mata Air Dan Pohon Pokki & Natural \\
4 & Kampung Harimau Situmeang & Natural \\
5 & Ulu Darat & Natural \\
6 & Hutan Flora Anggrek & Natural \\
7 & Gua Parmonangan & Natural \\
\hline
\end{tabular}


ISSN: 2580-4030 (Print) 2580-1775 (Online)

Vol 3, No. 1, (pp. 1-9), June, 2019

http://sjdgge.ppj.unp.ac.id

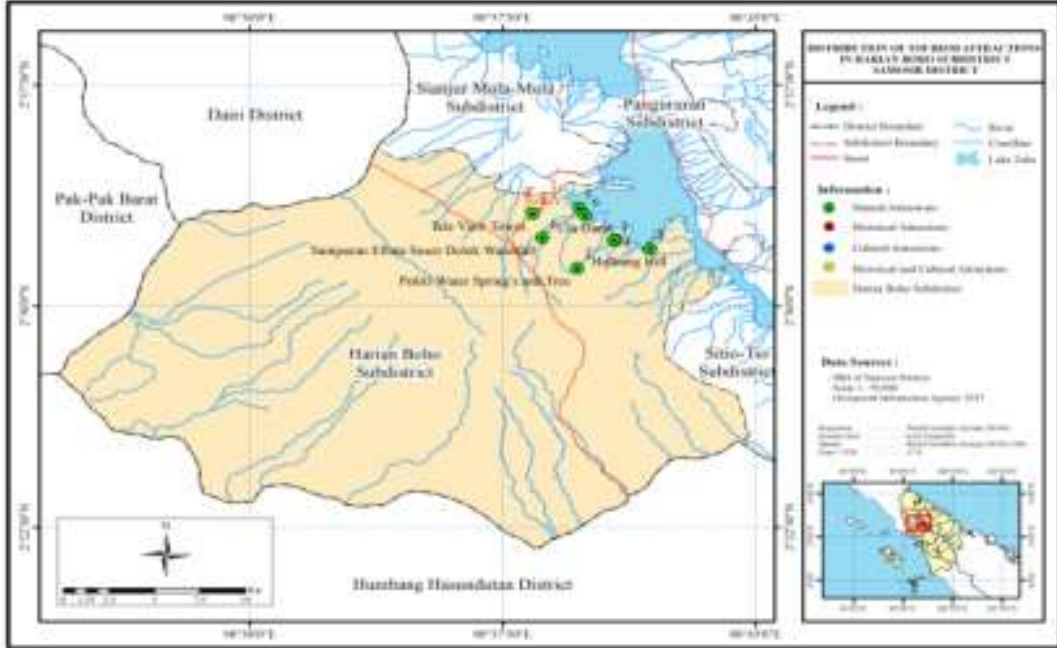

Figure 9. Map of Distribution of Tourist Sites in Harian Boho Subdistrict

\section{Kecamatan Ronggur Nihuta}

Covers an area of $94,87 \mathrm{~km}^{2}$ with capital of subdistrict is Ronggur Nihuta. All of tourist sites in Ronggur Nihuta Subdistrict are natural sites. This subdistrict has a list of tourist attractions shown in Table 9 and Figure 10

Table 9. Distribution of Tourist Sites in the Subdistrict of Ronggur Nihuta

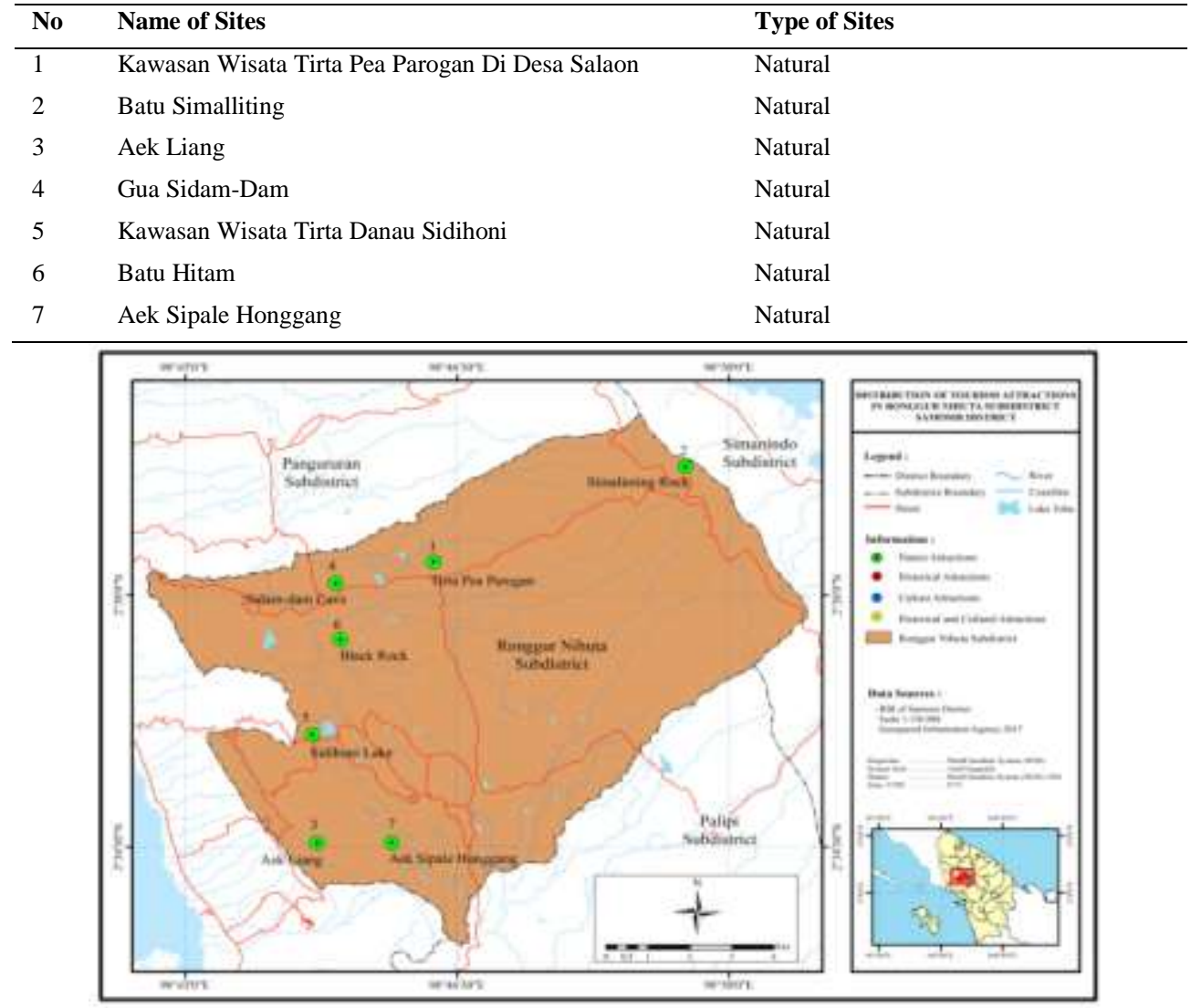

Figure 10. Map of Distribution of Tourist Sites in Ronggur Nihuta Subdistrict 


\section{Conclusion}

There are 39 natural tourist attractions, 14 historical attractions, 9 cultural attractions, 12 historical and cultural attractions and 1 spiritual attraction/religion. Distribution of most attractions are in Subdistrict of Simanindo (19 attractions), and in Sianjur Mula-mula (15 attractions). While, the rest is in 7 other subdistricts; Pangururan (10 attractions), Harian (7 attractions), Ronggur Nihuta (7 attractions), Onanrunggu (5 attractions), Nainggolan (5 attractions), Palipi (4 attractions), and Sitiotio (3 attractions). Tourism supporting facilities such as hotels and other accommodation are located in subdistricts of Simanindo (58 star hotels and jasmine classes), 18 jasmine-class hotels in Pangururan Sub-district, 4 jasmine-class hotels in Nainggolan Sub-district and 2 jasmine-class hotels in Palipi Subdistrict. While in other subdistricts do not have accommodation facilities. Spatial knowlege and distributions of tourist sites should assist policy makers and service providers in market segmentation, planning, and product expansion to local and international tourists .

\section{References}

Baviskar. 2017. Designing and Developing a GIS Database for Tourism in Aurangabad: A Review. International Journal of Computer Applications. Vol. 165 - No.5.

BPS Kabupaten Samosir. 2016. Kabupaten Samosir Dalam Angka.

Brown, et al., 2007. Tourism Destination Management. Washington: International Institute For Tourism Studies, The George Washington University.

Dinas Pariwisata. 2016. Seni dan Budaya Kabupaten Samosir

Hermon, D. 2009. Dinamika Permukiman dan Arahan Kebijakan Pengembangan Permukiman pada Kawasan Rawan Longsor di Kota Padang. Disertasi. IPB Bogor.

Hermon, D. 2010. Geografi Lingkungan: Perubahan Lingkungan Global. UNP Press.

Hermon, D. 2012. Mitigasi Bencana Hidrometeorlogi: Banjir, Longsor, Degradasi Lahan, Ekologi, Kekeringan, dan Puting Beliung. UNP Press. Padang.

Hermon, D. 2015. Geografi Bencana Alam. Jakarta: PT RajaGrafindo Persada.

Hermon, D. 2016. Mitigasi Perubahan Iklim. Rajawali Pers (Radjagrafindo).

Hermon, D. 2016. The Strategic Model of Tsunami Based in Coastal Ecotourism Development at Mandeh Regions, West Sumatera, Indonesia.Journal of Environment and Earth Science. Volume 6.

Hermon, D. 2017. Climate Change Mitigation. Rajawali Pers (Radjagrafindo).

Hermon, D. 2019. Evaluation of Physical Development of The Coastal Tourism Regions on Tsunami Potentially Zones in Pariaman City-Indonesia. International Journal of GEOMATE. Volume 17. Issue 59. p: 189-196. Geomate International Society.

Jovanovic, V. 2008. The Application of GIS and Its Components In Tourism. Yugoslav Journal of Operations Research Vol 18 (2008), Number 2, 261-272

Oktorie, O. 2017. A Study of Landslide Areas Mitigation and Adaptation in Palupuah Subdistrict, Agam Regency, West Sumatra Province, Indonesia. Sumatra Journal of Disaster, Geography and Geography Education. Volume 1. Issue. 1. p: 43-49. Master Program of Geography Education

Othman et al. 2010. A Geographic Information System Based Approach for Mapping Tourist Accommodations in the East Coast States of Malaysia. World Appl. Sci. J.,10 (Special Issue of Tourism \& Hospitality): 14-23.

Pendit. 2002. Ilmu Pariwisata Sebuah Pengantar Perdana. Jakarta: Pradya Paramita.

Rogerson, C.M. 2014. The Uneven Geography of Tourism in South Africa, African Journal of Hospitality, Tourism and Leisure 3, 1: 1-15, http//: www.ajhtl.com.

Williams, S. 2009. Tourism Geography: A New Synthesis. Abingdon: Routledge. 